\author{
Ks. Janusz Królikowski* \\ UPJPII, Kraków-Tarnów
}

\title{
TRÓJCA ŚWIĘTA I DOŚWIADCZENIE MISTYCZNE
}

Tajemnica Trójcy Przenajświętszej stanowi zasadę dziejów zbawienia i każdego dzieła zbawczego, dlatego też jest podstawą i punktem odniesienia życia chrześcijańskiego, co jednoznacznie potwierdza symbol wiary. Wskazuje na to jego struktura trynitarno-soteriologiczna. $Z$ tej racji autentyczne kształtowanie życia chrześcijańskiego potrzebuje odniesienia do Boga Trójcy. Rozwijające się dzisiaj zainteresowanie mistyką domaga się uwzględnienia tego pierwotnego faktu, a więc szukania jej odniesień trynitarnych, sięgając zarówno do doświadczeń historycznych, jak i do aspektów systematycznych tego zagadnienia.

„Bóg musi być trójjedyny” - napisał kiedyś nieco zaskakująco Hans Urs von Balthasar - gdyż tylko Jego trójjedyność, a właściwie to, co z niej wynika, jest gwarancją przyszłości człowieka i ludzkości ${ }^{1}$. Czytając zaproponowane wyjaśnienie oraz wiele innych pism szwajcarskiego teologa, wypada się zgodzić z tym stwierdzeniem. Trójjedyny Bóg otwiera przed człowiekiem rzeczywiście perspektywy nadziei i zaangażowania, których on szuka. Przywołaną wypowiedź warto połączyć z inną, której autorem jest tym razem Karl Rahner. Według niego „osoba pobożna jutra albo będzie «mistykiem», to znaczy kimś, kto czegoś «doświadczył», albo przestanie być pobożna"².

Przytoczone tutaj wypowiedzi nie tylko zasługują na uwagę, ale już sama intuicja teologiczna każe je zauważyć, ale także podjać nad nimi systematyczny namysł. Co więcej, wydaje się, że te dwie wypowiedzi można połączyć ze sobą i powiedzieć, że w obecnej sytuacji duchowej chodzi o głęboką, przeżytą, do-

* Ks. prof. dr hab. Janusz Królikowski - kapłan diecezji tarnowskiej, Uniwersytet Papieski Jana Pawła II, Katedra Teologii Systematycznej Wydziału Teologicznego Sekcja w Tarnowie; e-mail: janusz.krolikowski@upjp2.edu.pl; ORCID: 0000-0003-3929-6008.

1 H.U. von Balthasar, Duch chrześcijański, tłum. Z. Włodkowa, Paris 1976, s. 63.

2 K. Rahner, Frömmigkeit früher und heute, w: tenże, Schriften zur Theologie, t. 7, Einsiedeln 1966, s. 21. 
świadczoną, jak dzisiaj chętnie mówimy, to znaczy mistyczną, więź chrześcijanina z Trójcą Przenajświętszą, będącą transcendentną i pierwotną zasadą dziejów zbawienia oraz pierwszym przedmiotem wiary chrześcijańskiej. Właściwie można powiedzieć, że mamy tutaj otwartość na samą istotę wiary chrześcijańskiej, w której splata się tajemnica Boga i odniesienie człowieka do niej - więź pogłębionej wiary, tworzącej wspólnotę z Bogiem zarówno ukazuje Boga w świecie, jak i zabezpiecza przyszłość człowieka w Bogu. To zagadnienie chcemy podjąć w niniejszym opracowaniu i wskazać na potrzebę jego dalszego rozwijania w teologii katolickiej.

\section{PRYMAT TRÓJCY ŚWIĘTEJ W WIERZE}

Doświadczenie duchowe pierwszych chrześcijan, zakorzeniając się w celebracji chrztu i Eucharystii, w sposób niejako pierwotny jest ewidentnie natchnione i wspierane, głównie przez wiarę chrystologiczną, a tym samym także coraz wyraźniej trynitarną. Na Zachodzie, zwłaszcza od czasów św. Augustyna, dzieje się to w sposób systematyczny i pogłębiony teologicznie. Daje się potem zauważyć przechodzenie tego w coraz szerszym zakresie do całej teologii, a tym samym także do duchowości i do mistyki chrześcijańskiejª ${ }^{3}$ W czasach współczesnych nurt trynitarny w mistyce, a także w inspirującej się nią teologii, na nowo zyskał na znaczeniu, zwłaszcza za sprawą wielu wpływowych mistyczek, jak np. św. Elżbieta od Trójcy Przenajświętszej (1880-1906), Adrienne von Speyr (1902-1967) czy Maria Julitta Ritz (1882-1966) ${ }^{4}$. Na poziomie przedmiotu mistyka chrześcijańska ze swej istoty ma charakter trynitarny, tak samo jak istotnie trynitarna jest treść wiary chrześcijańskiej. Innymi słowy, wyznanie Trójcy Świętej, Ojca, Syna i Ducha Świętego, będąc centrum wiary Kościoła, stanowi zatem zasadę i formę egzystencjalną przylgnięcia wiary dostępną dla każdego chrześcijanina, nawet dla tych, których udziałem są najwznioślejsze doświadczenia duchowe, czyli mistyczne. Dlatego jeśli chce się wskazać jakąś pewną drogę prowadzącą do Boga w indywidualnych i zbiorowych dziejach zbawienia, czy też odkryć wyraźne ,ślady" Jego obecności w dziejach człowieka i świata, nigdy nie można abstrahować od treści teologicznych, streszczonych w symbolu wiary. Dla bezpośredniej świadomości Kościoła symbol wiary stanowi zwartą „syntezę teologii” objawienia,

3 Por. K. Ruh, Storia della mistica occidentale, t. 1: Le basi patristiche e la teologia monastica del XII secolo, Milano 1995, s. 97-135.

4 Por. J. Castellano Cervera, Il mistero di Dio Uno e Trino nella testimonianza dei mistici cristiani, w: Il Dio di Gesù Cristo, red. G.M. Zangí, Roma 1982, s. 253-274; P.-W. Scheele, Schwester Maria Julitta Ritz. Maria und Marta zygleich, Würzburg 2017. 
którą Bóg wypełnił w Jezusie Chrystusie za pośrednictwem Ducha Świętego. Paul Claudel postawił sugestywne pytanie: „Czyż to credo, które codziennie powtarzamy z wiarą, nie jest niczym innym jak tylko syntezą tajemnic?"5.

Święty Atanazy, który w pierwszej połowie IV wieku wyjątkowo usilnie zabiegał o utrwalenie wiary katolickiej bronionej na Soborze Nicejskim w konfrontacji z herezją ariańską, przyczyniając się do ostatecznego zwycięstwa ortodoksji, w liście do Serapiona tak streścił główne treści wiary chrześcijańskiej:

Istnieje więc święta i doskonała Trójca, którą uznajemy w Ojcu, Synu i Duchu Świętym; nie ma w Niej nic poza Nią samą, nie ma w Niej żadnej zewnętrznej domieszki, nie składa się Ona ze Stwórcy i stworzenia, lecz cała jest mocą stwórczą i sprawczą; z natury swej jest jednolita i niepodzielna, i jednolite jest Jej działanie. Ojciec bowiem tworzy wszystko przez Słowo w Duchu Świętym, i w ten sposób zachowana jest jedność Świętej Trójcy. W Kościele głoszony jest jeden Bóg, „Ten, który jest ponad wszystkimi, przez wszystkich i we wszystkich". Ponad wszystkimi jest jako Ojciec, jako Początek i Źródło, przez wszystkich - to znaczy przez Słowo, we wszystkich w Duchu Świętym. Trójca jest więc Trójcą nie z nazwy i z pozoru, lecz jest Nią naprawdę i rzeczywiście. Jak bowiem Tym, który jest, jest Ojciec, tak samo też Tym, który jest, Bogiem ponad wszystkimi, jest Jego Słowo. Również Duch Święty nie jest pozbawiony istnienia, lecz bytuje i istnieje prawdziwie. [...] Taka jest właśnie wiara Kościoła ${ }^{6}$.

Wiara trynitarna, zanim została sformułowana literacko w Symbolu nicejskim, już w III wieku była pewnym znakiem rozpoznawczym prawowiernego chrześcijanina, czego świadectwa możemy znaleźć u św. Cypriana z Kartaginy. Nauczając kandydatów do chrztu, św. Augustyn utrwalił religijne znaczenie „symbolu”, pochodzącego od używanego w świeckim języku greckiego słowa syn-ballein, to znaczy „połączyć razem”, „zestawić” pewne prawdy, a w ten sposób określić „regułę wiary”, będącą znakiem rozpoznawczym chrześcijan? ${ }^{7}$ W homilii przypisywanej Augustynowi znajdujemy takie wyjaśnienie: „To, co po grecku jest nazywane symbolem (symbolum), po łacinie jest nazywane zbiorem (collatio) ${ }^{8}$. Jest zbiorem, ponieważ została zebrana w całość wiara prawa katolickiego"".

P. Claudel, Le Cantique des cantiques, Paris 1954, s. 216.

6 Atanazy, Listy do Serapiona [1, 28-29], tłum. S. Kalinkowski, Kraków 1996, s. 101-102 (Źródła Myśli Teologicznej, 2).

7 Por. Augustyn, Sermo 213, 2 (In traditione Symboli), w: Augustyn, Piotr Chryzolog, Wenancjusz Fortunatus, Symbol Apostolski w nauczaniu ojców, tłum. L. Gładyszewski, Kraków 2010, s. 76-77 (Źródła Myśli Teologicznej, 53).

8 Nawiązując do tego określenia w polskiej tradycji, mówimy także o „Składzie apostolskim”.

9 Pseudo-Augustyn, Sermo 241, PL 39, 2190: „Quod graecae symbolum dicitur latine collatio nominatur. Collatio ideo, quia in unum collata catholicae legis fides". 
Augustyn wskazał zarazem, że symbol ma charakter normatywny. Mówił on do nowo ochrzczonych, przekazując im Symbol:

Nadszedł czas, abyście otrzymali Symbol, w którym krótko zawarte jest to wszystko, w co wierzymy dla zbawienia wiecznego. Nosi to nazwę Symbolu ze względu na pewne podobieństwo w przenośnym znaczeniu do tego słowa, którym jako „symbol” określana jest umowa, jaką między sobą zawierają kupcy, a która w ich społeczności ma zobowiązywać do wiernego jej zachowywania. I wasza społeczność tworzy umowę dotyczącą spraw duchowych, abyście byli podobni do kupców poszukujących pięknej perty ${ }^{10}$.

Łacińskie collatio, które często powraca w wypowiedziach ojców Kościoła, nie oznacza więc zgromadzenia katechumenów, ale zbiór dwunastu artykułów wiary, które zgodnie z najstarszą tradycją zostały sformułowane przez dwunastu apostołów, zgromadzonych w Duchu Świętym. Święty Ambroży sformułował tę tradycję, która spotkała się potem z bardzo szerokim przyjęciem. Jeśli takie przypisane Symbolu apostołom ma faktycznie charakter legendarny, to nie jest legendą istnienie podstaw tego credo, począwszy od ostatnich dziesięcioleci II wieku ${ }^{11}$. Już w tym okresie mówiono - wraz z Tertulianem i ze św. Ireneuszem - o ,regule wiary”, „regule niezmiennej i nie podlegającej modyfikacjom”, sięgającej epoki apostolskiej $^{12}$. Pomijając niewielkie warianty, Symbol Apostolski odpowiada wyznaniu wiary używanemu w Kościele w Rzymie. Został on przekazany w języku łacińskim przez św. Rufina z Akwilei, a po grecku przez Marcelego z Ancyry ${ }^{13}$. Dzięki prestiżowi, którym cieszył się Kościół w Rzymie, a zwłaszcza jego normatywnej roli w przekazywaniu wiary, symbol tego Kościoła szybko stał się wspólnym dziedzictwem całego Zachodu chrześcijańskiego i znakiem rozpoznawczym jego tożsamości doktrynalnej. W XVI wieku przyjęły go także wyznania zrodzone $\mathrm{z}$ reformacji, włączając do swoich katechizmów ${ }^{14}$.

10 Augustyn, Sermo 212 (In traditione Symboli), w: Augustyn, Piotr Chryzolog, Wenancjusz Fortunatus, Symbol Apostolski w nauczaniu ojców..., s. 69.

11 Por. M. Starowieyski, Legenda o powstaniu Składu Apostolskiego, w: Symbol Apostolski w nauczaniu i sztuce Kościoła, red. R. Knapiński, Lublin 1997, s. 51-62.

12 H. de Lubac, La Foi chrétienne. Essai sur la structure du Symbole des Apôtres, Paris 1969, s. 20-21.

13 Por. V. Peri, Rufino e il simbolo della Chiesa di Aquileia. La tradizione culturale del Simbolo Apostolico nella ,stilizzazione storica” occidentale, w: tenże, Da Oriente e da Occidente. Le Chiese cristiane dall 'impero romano all'Europa moderna, red. M. Ferrari, t. 2, Roma-Padova 2002, s. 750-778 (Medioevo e Umanesimo, 108).

14 Por. M. Luter, Mały katechizm, w: Wybrane księgi symboliczne Kościoła ewangelicko-augsburskiego, tłum. A. Wantuła, W. Niemczyk, Warszawa 1980, s. 34-35; M. Luter, Duży katechizm, w: Wybrane księgi..., s. 47. 
Pod koniec VI wieku, wraz IV Synodem Toledańskim (589 r.), Kościół katolicki na Zachodzie przyjął Symbol nicejsko-konstantynopolitański, który począwszy od potwierdzenia jego wiążącego znaczenia doktrynalnego na Soborze Chalcedońskim (451 r.), był powszechnie uznawany na chrześcijańskim Wschodzie za znak rozpoznawczy i nienaruszalną ,regułę” tożsamości wiary katolickiej. Obydwa Symbole, zarówno apostolski, jak i nicejsko-konstantynopolitański, są ściśle trynitarne co do struktury i co do treści ${ }^{15}$.

Pierwsze pokolenia chrześcijańskie rozumiały bardzo konsekwentnie prymat wymiaru trynitarnego w życiu chrześcijańskim, zapoczątkowanym przez chrzest w imię Trójcy. Dowodzą tego liczne świadectwa literackie i teologiczne ${ }^{16}$. Warto jednak zwrócić uwagę na to, że posiadamy także liczne i niezwykle ciekawe świadectwa archeologiczne, choć ich wymowa jest mało doceniana w teologii. Ich szczególną rolę należy wiązać zwłaszcza z ich syntetycznym charakterem, a tym samym bezpośrednim wskazywaniem na to, co istotne. Jednym z tych świadectw jest pochodząca z VI wieku z kościoła w środkowej Syrii inskrypcja trynitarna:

Ojciec nas zbudował,

Syn utwierdził,

Duch umocnił.

Niepodzielna Święta Trójco, błogosław

Moje wejście i moje wyjście

Od teraz i na zawsze. Amen ${ }^{17}$.

Przytoczona inskrypcja, pogłębiona teologicznie i egzystencjalnie, wyraźnie wskazuje, że Bóg w jedności swojej boskiej natury i w komunii swoich trzech osób witalnie oddziałuje na kształtowanie się, urzeczywistnianie i prowadzenie do wypełniania życia każdego chrześcijanina. Dlatego w budowaniu „domu” chrześcijańskiego i całego Kościoła zawsze i we wszystkim współdziałają - niczym niestrudzeni „artyści”, jak mówił już św. Ireneusz ${ }^{18}$ - Ojciec, Syn i Duch Święty. To rozumienie trynitarnej tajemnicy Boga, „początku i końca” (Ap 21,6; 22,13) całego życia chrześcijańskiego, nie jest niczym szczególnym.

15 Por. J.A. Jungmann, Catechetica, Roma 1956, s. 337-344; J. Królikowski, Tajemnica Trójjedynego. Studia z teologii trynitarnej, Kraków 2015, s. 157-202 (Ministerium Expositionis, 2).

16 Por. A. Hahn, G.L. Hahn, Bibliothek der Symbole und Glaubensregeln der alten Kirche, Breslau $1897^{3}$.

17 L. Jalabert, R. Monterede, Inscriptions greques et latines de la Syrie, Paris 1929, nr 1677: „Pater nos fundavit, Filius aedificavit, Spiritus Sanctus consolidavit".

18 Por. H.U. von Balthasar, Chwała. Estetyka teologiczna, t. 2: Modele teologiczne, cz. 1: Od Ireneusza do Bonawentury, thum. E. Marszał, J. Zakrzewski, Kraków 2007, s. 66-86. 
W kontekście naszego zagadnienia można przypomnieć, że podobne świadectwa są bardzo liczne zarówno na Wschodzie, jak i na Zachodzie.

Całe życie ochrzczonego jest opisywane i ożywiane wymiarem trynitarnym, zakorzenionym w wyznaniu wiary; co więcej, nie ma ona żadnych analogii w innych tradycjach religijnych. Celebracje sakramentów i liturgia, o czym najbardziej wyraźnie świadczą modlitwy (anafory) eucharystyczne, są oparte w swojej strukturze i treści na odniesieniu do Boga Trójcy ${ }^{19}$. To odniesienie stanowi ich zasadę i fundament, źródło natchnienia i formę uświęcenia, krótko mówiąc, jest pierwszorzędną treścią „doświadczalnego” poznania Boga ${ }^{20}$. Można więc powiedzieć, że

[...] mistyka chrześcijańska jest mistyką trynitarną, ponieważ w Jezusie Chrystusie cała Trójca objawia się i daje. Nasz Bóg nie jest jakimś Nieskończonym, tak obojętnym, jak nieograniczonym, który naraża się na niebezpieczeństwo zagubienia się ze względu na naszego ducha, w nie wiem jakiej pustej przestrzeni. [...] Nie jest jakimś nieskończonym rozproszeniem, ale koncentracją; w Nim zagęszcza się tajemnica bytu osobowego ${ }^{21}$.

Bóg, w którego my, chrześcijanie, wierzymy i którego adorujemy w Jego najwyższej tajemnicy, jest Bogiem ,nieskończenie wolnym, [...] jest tym, kto w sposób wolny wymyśla strukturę świata i stwarza go, [...] jest On Trójjedyny i jest tym, kto w Jezusie Chrystusie staje się człowiekiem"”22. Postać objawienia chrześcijańskiego „w żadnym razie nie ujawnia się jako phainomenon prostej Jedności, ale jako uwidocznienie się i stanie się przedmiotem doświadczenia Trójjedynego Boga"23.

Ta transcendentna i trójosobowa boska rzeczywistość jest tym, co jest dane mistykowi poznać przez kontemplację wlaną, w sposób świadomy i w formie uszczęśliwiającej bądź też w sposób bolesny, dokonujący jego oczyszczenia. Dlatego można w tym miejscu powiedzieć na temat relacji między symbolem wiary i mistyką, że z punktu widzenia swojej treści, jak również z punktu widzenia swego kształtu psychologicznego bądź swojej pozycji w ramach życia duchowego,

19 Por. E.J. Kilmartin, Christian Liturgy: Theology and Practice. I. Systematic Theology of Liturgy, Kansas City 1988, s. 100-123.

20 Na temat rozwoju pojęcia doświadczenia w duchowości chrześcijańskiej por. E. Falque, Le livre de l'expérience. D'Anselme de Cantorbéry à Bernard de Clairvaux, Paris 2017.

21 H. de Lubac, Mistica e mistero cristiano, Milano 1979, s. 31.

22 H.U. von Balthasar, Chwała. Estetyka teologiczna, t. 1: Kontemplacja postaci, thum. E. Marszał, J. Zakrzewski, Kraków 2008, s. 375.

23 Tamże, s. 377. 
a także z racji swojej transcendencji doświadczenie trynitarne jawi się jako właściwy typ chrześcijańskiego doświadczenia mistycznego ${ }^{24}$.

\section{TRÓJCA PRZEDMIOTEM DOŚWIADCZENIA MISTYCZNEGO}

Czym jest mistyka? Na czym polega specyfika mistyki chrześcijańskiej? Właśnie na wskazaniu i uwypukleniu egzystencjalnym związku między tajemnicą Trójcy Świętej i doświadczeniem mistycznym polega odkrycie nowości, a więc także oryginalności i głębi mistyki chrześcijańskiej w stosunku do każdego innego analogicznego doświadczenia religijnego, które można spotkać zarówno w religiach starożytnych, jak i współczesnych. Już same słowa „,mistyka” i „,misterium" (tajemnica) są ze sobą wewnętrznie powiązane. Począwszy od kultów misteryjnych w epoce helleńskiej i rzymskiej, mistyka zawsze była powiązana ze zjawiskami religijnymi ${ }^{25}$.

Rzeczownik „mistyk” (mystês) i przymiotnik „mistyczny” (mystikos) pochodzą od greckiego czasownika myein, oznaczającego „zamknąć oczy lub usta”, aby nie mówić o tym, co się widziało lub słyszało. Obydwa pojęcia mają więc wspólny źródłosłów. Historycznie i semantycznie z tym czasownikiem łączy się także czasownik myeîn, oznaczający „wtajemniczyć”, „dać poznać tajemnice”, „wzbudzić ukryte działania”. Mystês świata greckiego to ktoś wprowadzony w tajemnice kultów misteryjnych i w sekrety, które nie miały być znane absolutnie nikomu.

W Piśmie Świętym mystês występuje tylko dwa razy (Mdr 8,4; 12,6), przy czym w drugim przypadku jest użyte w celu zdemaskowania aberracji religijnej obecnej w kultach kananejskich ${ }^{26}$. W Ewangeliach synoptycznych pojęcie mysterion pojawia się tylko w jednym kontekście, gdy Jezus, zwracając się do apostołów, mówi do nich: „Wam dana jest tajemnica królestwa Bożego” (Mk 4,11; Mt 13,11; Łk 8,10). Pojęcie częściej powraca w Listach św. Pawła, w których nie ma jednak żadnego związku z kultami ezoterycznymi świata greckiego i rzymskiego. ,Tajemnica” (misterium) prawie zawsze oznacza u apostoła przedmiot objawienia Bożego, to znaczy manifestację i ostateczne wypełnienie w Jezusie Chrystusie zamysłu Bożego, który wcześniej pozostawał ukryty. Ta tajemnica posiada jednak

24 Por. Ch.A. Bernard, L'esperienza spirituale della Trinità, w: La mistica. Fenomenologia e riflessione teologica, red. E. Ancilli, M. Paparozzi, t. 2, Roma 1984, s. 319.

25 Por. M. Eliade, Historia wierzeń i idei religijnych, t. 1: Od epoki kamiennej do misteriów eleuzyńskich, tłum. S. Tokarski, Warszawa 1988, s. 249-259.

26 Por. G. Finkenrath, Mistero, w: Dizionario dei concetti biblici del Nuovo Testamento, red. L. Coenen, E. Beyreuther, H. Bietenhard, Bologna $1989^{4}$, s. 1023-1027 . 
wymiar angażujący wierzącego, a tym samym kształtujący jego relację do Boga, którego ta tajemnica przybliża, mimo jej niewymowności i nieograniczoności ${ }^{27}$.

Jeśli jednak chodzi o mistykę chrześcijańską - zanim przejdzie się na poziom psychologiczny lub nawet somatyczny, a więc także na poziom nadzwyczajnych charyzmatów i zjawisk psychosomatycznych, które nierzadko towarzyszą doświadczeniu mistycznemu - jej natura oraz charakterystyczne cechy i elementy, które jej dotyczą, muszą być analizowane i określane na poziomie właściwej dla niej specyficznej treści teologicznej. Tym, co w dziejach duchowości chrześcijańskiej określa mistykę, jest przede wszystkim przedmiot kontemplacji. Tradycyjnie mistyka jest definiowana jako „doświadczalne poznanie Boga, posiadane w ujęciu jednoczącej miłości”28. Chodzi o doświadczenie niemające charakteru pojęciowego, ale o egzystencjalne przeżycie Boga w Jego naturze, łącznie z Jego rzeczywistością transcendentną oraz w Jego przymiotach (np. miłosierdzie). Mimo zróżnicowanych wyjaśnień tego doświadczenia teologowie są zgodni co do przyjmowania w nim pewnych wspólnych elementów, dzięki którym można opisać jego właściwości i charakter religijny. Jest to zatem

[...] doświadczenie Boga obecnego pod postacią poznania ogólnego, a zarazem zakrytego, bogatego i nasycającego - miłości przenikającej i opanowującej biernie duszę w jej wewnętrznej głębi; wywołuje ono wrażenie bierności pod wszechobecnym panowaniem Boga; zachodzi totalna niemożność wywołania, przedłużania bądź ponawiania takich doświadczeń, a także przewidzenia ich nadejścia i ich końca; nie można zatem wyrazić za pomocą języka potocznego doznanych wrażeń, a przede wszystkim przekazać ich w sposób wystarczająco jasny temu, kto nie doświadczył niczego podobnego ${ }^{29}$.

Mimo tych ograniczeń i ich w pewnym sensie ,negatywnego” znaczenia pozostaje prawdą, że zjawisko mistyczne jest ,najwznioślejszą i najgłębszą manifestacją religii” i że „mistyka prowadzi nas do samego serca religii, z którą jest nierozerwalnie związana"30. Dlatego też odniesienie do mistyki posiada zasadnicze znaczenie dla Kościoła, a nawet do życia społecznego w wielości jego wymiarów. Karol Górski, prekursor i zasłużony badacz dziejów mistyki w Polsce, stwierdził wnikliwie i w pełni słusznie: „U podstaw wielkich ruchów religijnych czy kulturalnych tkwi takie czy inne ustosunkowanie do mistyki"31.

27 Por. L. Bouyer, Mysterion. Dal mister alla mistica, Città del Vaticano 1998, s. 15-51.

28 J. Gerson, O teologii mistycznej [28, 6], thum. M. Jakubowska, Kęty 2012, s. 129: „Cognitio experimentalis habita de Deo per amoris unitivi complexum".

29 J. de Guibert, La spiritualità della Compagnia di Gesù. Saggio storico, Roma 1992, s. 22.

30 E. Ancilli, Premessa, w: La mistica..., t. 1, s. 11-12.

31 K. Górski, Studia i materiały do dziejów duchowości, Warszawa 1980, s. 9. 
Mistyka jest „kosztującym doświadczeniem Absolutu”, jak - w duchu św. Bonawentury - stwierdził Jacques Maritain. Jest jednak tak samo prawdą, że tajemnica Trójcy Świętej, którą konstytuuje jedyność Boga w rozróżnieniu i komunii trzech Osób Bożych: Ojca, Syna i Ducha Świętego, stanowi szczyt chrześcijaństwa i jego centrum. Świadczy o tym zarówno wyznanie wiary Kościoła, jak i cały dynamizm jego życia sakramentalnego i liturgicznego, na gruncie którego rodzi się i kształtuje osobista wędrówka doskonałości każdego chrześcijanina powołanego do służby Bożej i społecznej w miłości. Mistyka chrześcijańska jest w swej istocie mistyką trynitarną, gdyż wyrasta z trynitarnej wiary i z jej przeżywania w relacji do Boga Trójcy, jak i poszczególnych Osób Bożych.

Można więc tytułem syntezy przytoczyć następujący opis mistyki chrześcijańskiej, ukazujący jej naturę i specyfikę:

Mistyka chrześcijańska jest zapoczątkowana przez objawienie i przez działanie Boga, które zapewnia wiernemu możliwość boskiego zjednoczenia, urzeczywistniając je nie za pośrednictwem procesów naturalistycznych, ale przez udzielenie zasady życia nadprzyrodzonego, łaski, która udzielona w chrzcie zostaje przez mistyka uchwycona na poziomie świadomości, w szczególnym doświadczeniu absolutnie wlanym, a wiec darmowym. Chrześcijaństwo ukazuje w mistyce swoją głęboką naturę i swoje ostateczne powołanie: spotkanie, posiadanie, oglądanie Boga, urzeczywistniane już na ziemi, jakby antycypację wieczności, przez wlanie czystej wiary i zespalającej miłości ${ }^{32}$.

W sensie ścisłym można zdefiniować mistykę chrześcijańską jako „doświadczenie Boga obecnego i nieskończonego, wywołane w duszy przez specjalne poruszenie Ducha Świętego"33.

\section{KRYTERIA MISTYKI CHRZEŚCIJAŃSKIEJ}

Szukając właściwego usytuowania mistyki chrześcijańskiej w relacji do pozachrześcijańskich przejawów mistyki i określenia różnicy w stosunku do nich, Hans Urs von Balthasar wskazał trzy podstawowe kryteria teologiczne określające specyfikę mistyki chrześcijańskiej i pozwalające dokonać jej weryfikacji i oceny ${ }^{34}$.

32 E. Ancilli, Premessa, w: La mistica..., t. 1, s. 12.

33 E. Ancilli, La mistica alla ricerca di una definizione, w: La mistica..., t. 1, s. 22.

34 Por. H.U. von Balthasar, Per determinare dove si collochi la mistica cristiana, w: tenże, Lo Spirito e l'istituzione. Saggi teologici-IV, Brescia 1979, s. 256-278. 
Pierwsze z tych kryteriów dotyczy treści - chodzi mianowicie o prymat tajemnicy Jedyności i Troistości Boga łaskawie i zbawczo objawionego przez Jezusa Chrystusa. Wobec Niego od wierzącego jest wymagana pełna dyspozycyjność wiary jako odpowiedź na wezwanie Boga, by pójść za Jezusem Chrystusem jako archetypem posłuszeństwa w pełnieniu woli Ojca. Drugie kryterium dotyczy osobistego doświadczenia, którym dla każdego chrześcijanina przeżywającego swoją wiarę staje się tajemnica krzyża i zmartwychwstania Jezusa, a więc także wylanie darów Ducha Świętego w Kościele, mające swoje źródło w tajemnicy paschalnej Chrystusa. Na trzecim miejscu sytuują się, wyraźnie odróżnione od dwóch pierwszych kryteriów i im podporządkowane, ,pewne szczególne doświadczenia udzielane poszczególnym wierzącym - ze względu na dobro innych - doświadczenia, które, aby zostały właściwie wykorzystane, zakładają wielką czystość intencji, podczas gdy same przez się nie stanowią one kryterium, aby weryfikować taką przejrzystość intencji” ${ }^{35}$.

Przywołane kryteria nabierają szczególnego znaczenia zarówno ze względu na to, by w ich perspektywie móc ocenić pewne nadzwyczajne techniki nastawione na osiągnięcie doświadczeń mistycznych, jak i ze względu na to, by dokonać weryfikacji samej mistagogii chrześcijańskiej w relacji do danych biblijnych i teologicznych wiary Kościoła. Opierając się na dynamice objawienia biblijnego i dziejów zbawienia, trzeba zatem jednoznacznie powiedzieć, że to nie człowiek jako pierwszy podejmuje inicjatywę, aby wyruszyć na poszukiwanie Boga - aby spotkać Absolut. Przeciwnie, zawsze Bóg zwraca się nieoczekiwanie i dobrowolnie w kierunku człowieka i go poszukuje, aby go stworzyć, wyzwolić z grzechu i śmierci, aby go zbawić. Wybranie Abrama, Mojżesza i proroków, jak cała teologia przymierza i wcielenie Słowa, jasno potwierdzają tę ekonomię Boga zwracającego się do człowieka, do jego wolności i do jego osobistej odpowiedzialności. Dzieje zabawienia są nieustannym wychodzeniem Boga naprzeciw człowiekowi, co pozwala uznać, że to wychodzenie jest zasadniczym elementem Jego obrazu, a tym samym powinno być również wpisane w ludzkie odniesienie do Niego, a to z kolei powinno kształtować także właściwe myślenie teologiczne.

Przez słowo Boga, który łaskawie powołuje do istnienia i do łaski, człowiek jest wezwany jako osoba w pełni swojej indywidualności oraz jest pobudzany do udzielenia tak samo wolnej i odpowiedzialnej odpowiedzi; co więcej, chodzi o udzielenie Bogu odpowiedzi w miłości, która tylko w tej perspektywie staje się odpowiedzią pełną, na miarę przykładu danego przez Chrystusa. W tym sensie ma rację von Balthasar, gdy stwierdza, że ideałem doskonałości chrześcijańskiej jest szczera dyspozycyjność wobec Boga:

35 Tamże, s. 278. 
Jeśli po chrześcijańsku „dyspozycyjność” jest odpowiedzią na wezwanie Boże, wówczas nie jest ona już punktem wyjścia inicjatywy ludzkiej, ale podłożem dla pojawienia się inicjatywy Boga, który chce postawić stopę na ziemi - w sercach. Methodos ,pójścia za” jak za archetypem jest Chrystus, który przychodzi na świat, aby pełnić wolę Ojca, tym bardziej że - zgodnie z teologią Nowego Testamentu - Jego bycie człowiekiem jest już wyrazem Jego posłuszeństwa ${ }^{36}$.

Dziewica Maryja przez swoje bezwarunkowe „tak”, wypowiedziane w odpowiedzi na słowo Boże, i działanie w niej Ducha Świętego jest pierwotnym, w pełni zrealizowanym, obrazem i wzorem tej oblubieńczej dyspozycyjności, oczekiwanej przez Jezusa ze względu na pójście za Nim w „,ciemną noc” doświadczenia agonii i mroku krzyża ${ }^{37}$.

Właściwie każdy chrześcijanin, na mocy chrztu udzielanego i przyjętego w imię Trójcy $($ Mt 28,19) i dzięki darowi Ducha Świętego, jest powołany do urzeczywistniania w swoim życiu - w perspektywie eschatologicznej - „doświadczalnego poznania Boga", poznania Boga w Bogu, kontemplacji Boga w Jego niedostępnym i promieniującym świetle (por. $1 \mathrm{Tm} 6,16$ ). Już starotestamentalny psalmista wyznawał: „W Twej światłości oglądamy światłość” (Ps 36[35],10). Jezus w czasie ostatniej wieczerzy prosił Ojca, aby udzielił wierzącym w Niego daru życia wiecznego, to znaczy trynitarnego poznania Boga: „A to jest życie wieczne: aby znali Ciebie, jedynego prawdziwego Boga, oraz Tego, którego posłałeś, Jezusa Chrystusa" (J 17,3). W tym samym kontekście św. Jan przytacza inne słowa Jezusa, stanowiące jakby syntezę całej duchowości chrześcijańskiej naznaczonej trynitarnym zamieszkiwaniem Boga w człowieku - aż do najwznioślejszych doświadczeń mistycznych: „Jeśli Mnie kto miłuje, będzie zachowywał moją naukę, a Ojciec mój umiłuje go i przyjdziemy do niego, i mieszkanie u niego uczynimy" (J 14,23). Najwznioślejszym celem całego życia chrześcijańskiego, a tym bardziej doświadczenia mistycznego, jest ,współuczestnictwo [...] z Ojcem i z Jego Synem, Jezusem Chrystusem" (1 J 1,4).

Święty Paweł z naciskiem stwierdza wielokrotnie, że chrześcijanie stali się podobni do trwałego mieszkania Boga Trójcy, który mieszka w człowieku uświęconym i usprawiedliwionym jak w świątyni. Ochrzczeni są więc „świątynią Bożą" (1 Kor 3,16-17), „świętą w Panu świątynią" (Ef 2,21) i ,przybytkiem Ducha Świętego" (1 Kor 6,19). W ważnej wypowiedzi z Listu do Efezjan św. Paweł definiuje, odnosząc się do obrazu świątyni, trynitarną podstawę całego życia chrześcijańskiego, od jego narodzin do jego wypełnienia: „W Nim [Jezusie Chrystusie] zespalana cała budowla rośnie na świętą w Panu świątynię, w Nim i wy także

$36 \quad$ Tamże, s. 269.

37 Papież Jan Paweł II zwrócił uwagę na to zagadnienie w encyklice Redemptoris Mater, nr 17. 
wznosicie się we wspólnym budowaniu, by stanowić mieszkanie Boga przez Ducha” (Ef 2,21-22). W tej duchowej budowli Jezus Chrystus stanowi ,żywy kamień”, „wybrany i drogocenny”, ale także chrześcijanie są „,niby żywe kamienie”, a to oznacza, że „stanowią święte kapłaństwo, dla składania duchowych ofiar, miłych Bogu przez Jezusa Chrystusa" (1 P 2,4-6).

\section{„EKSTAZA” I MISTYKA}

Dzieje duchowości chrześcijańskiej potwierdzają, że człowiek miał i ma możliwość doświadczenia mistycznego sięgające aż do ekstazy, to znaczy aż do wyjścia z siebie i do bycia porwanym przez Boga ${ }^{38}$. Jest to możliwe, ponieważ sam Bóg jako pierwszy dokonał „ekstazy” (ek-stase): w Jezusie Chrystusie wieczne Słowo stało się człowiekiem (J 1,14), Bóg dał się poznać w swoim wewnętrznym bycie jako Trójjedyny: Ojciec, Syn i Duch Święty. Słowo Boże wyszło z łona Ojca, aby zniżyć się do człowieka i niejako stanąć po jego stronie, a tym samym ostatecznie otworzyć przed nim dostęp do nieba. Na ludzkim obliczu Jezusa Chrystusa jaśnieje chwała Boża, która z Jego oblicza, jak z najczystszego zwierciadła, rozlewa się w ludzkich sercach, umożliwiając poznanie chwały Boga, to znaczy Jego boskości (por. 2 Kor 4,6).

Pierwsza prefacja na Boże Narodzenie bardzo jasno wyraża dynamikę zachodzącą między „ekstazą”, czyli manifestacją Boga w Jezusie Chrystusie, i „porwaniem", czyli podniesieniem człowieka do Boga na mocy Jego czystego daru: „Przez tajemnicę Wcielonego Słowa zajaśniał oczom naszej duszy nowy blask Twojej światłości, abyśmy poznając Boga $\mathrm{w}$ widzialnej postaci, zostali przezeń porwani do umiłowania rzeczy niewidzialnych". Ekstazie Boga i Jego chwały kabôd w Starym Testamencie, doxa w Nowym Testamencie - ze strony człowieka odpowiada percepcja, ogląd w wierze, a więc kontemplacja objawionej chwały Bożej. Ek-stase Boga, którą von Balthasar uczynił ośrodkiem swojej estetyki teologicznej, jest podstawą wiary i doświadczenia kontemplacyjnego, ponieważ Bóg sam z siebie przyjmuje postać, a w ten sposób pozwala się widzieć, słyszeć, dotykać $(1 \mathrm{~J} 1,1)^{40}$. Wszystkie aspekty ludzkie, zwłaszcza psychologiczne, nie są w tym przypadku wprost brane pod uwagę i opisywane - zostają one odkry-

\footnotetext{
38 Por. H.U. von Balthasar, Thomas und die Charismatik. Kommentar zu Thomas von Aquin „Summa Theologica”, Quaestiones II II 171-182. Besondere Gnadengaben und die zwei Wege menschlichen Lebens, Freiburg i. Br. 1996, s. 389-395, 445-454.

39 Por. G. Marchesi, Sul volto di Cristo rifulge la Gloria del Padre (2 Kor 4,6), „La Civiltà Cattolica" 2001, t. 4, s. 240-253.

40 Por. H.U. von Balthasar, Chwata ..., t. 1, s. 278-286.
} 
te dopiero wówczas, gdy dokonuje się bliższego poznania działania Boga, który zawsze działa odpowiednio do ludzkiej kondycji, do poziomu psychicznego i do wrażliwości człowieka. Wyrosła z tych badań psychologia mistyki przyczyniła się do głębszego poznania człowieka pod względem psychicznym. Odejście psychologii od zainteresowania zjawiskami religijnymi i mistycznymi przyczynia się do jej znacznego zubożenia.

Doświadczenie ,porwania” do Boga, do poznania Go w wymiarze trynitarnym otrzymane przez absolutnie darmowy dar Boga i przeżyte w różnych ,stanach” duchowych i psychologicznych kontemplacji-zostało po raz pierwszy opisane przez św. Ignacego Loyolę. Za jego opisem poszli potem św. Jan od Krzyża i św. Teresa od Jezusa ${ }^{41}$. W autobiografii św. Ignacego znajdujemy następujące świadectwo:

Miał on wielkie nabożeństwo do Trójcy Przenajświętszej i codziennie odmawiał modlitwę do trzech Osób Boskich osobno. [...] I na całe życie pozostało mu to wrażenie, tak iż doznawał wielkiej pobożności, ilekroć modlił się do Trójcy Świętej²

Wizje intelektualne i intuicje duchowe, których przedmiotem jest kontemplacja Trójcy, wpisują się dogłębnie w całą wędrówkę duchową św. Ignacego, począwszy od jego pobytu w Manresie aż do słynnej wizji w La Storta pod Rzymem w listopadzie 1537 roku. Potem miały one jeszcze swoją kontynuację i konkretyzację. W swoich doświadczeniach św. Ignacy czuł bezpośrednią i osobową więź z Trójcą Przenajświętszą, której doświadczał zwłaszcza w czasie Mszy Świętej. Zanotował między innymi:

Doznawałem też wielkich oświeceń duchowych, iż mi się zdawało, że tak [wszystko] pojmuję, jakby już nie było nic więcej do poznania w przedmiocie Trójcy Przenajświętszej. A przyczyną tego było to, że przedtem, chcąc znaleźć pobożność w Trójcy Świętej, nie chciałem już szukać ani znaleźć w modlitwie do Ojca i nie przykładałem się do tego, bo mi się zdawało, że nie ma pociechy ani nawiedzenia w Trójcy Przenajświętszej. Ale w tej mszy poznałem, odczułem albo zobaczyłem, Dominus scit (2 Kor 12,2), że gdy się mówi do Ojca, gdy się widzi, że jest On Osobą Trójcy Przenajświętszej, że to pociąga do miłości całej Trójcy, i to tym bardziej że inne osoby są w Nim co do istoty. To samo odczuwałem w modlitwie do Syna, to samo w modlitwie do Ducha Świętego, radując się każdą [z Osób Boskich], doznając pociech i przypisując je [wszystkim trzem Osobom] i weseląc się, że pochodzą one od wszystkich trzech ${ }^{43}$.

41 Por. Ch.A. Bernard, L'esperienza spirituale della Trinità, w: La mistica..., s. 296.

42 Ignacy Loyola, Opowieść pielgrzyma, czyli autobiografia [28], w: tenże, Pisma wybrane, t. 1: Komentarze, oprac. M. Bednarz, przy współpracy S. Filipowicza, R. Skórki, Kraków 1968, s. 191-192.

43 Ignacy Loyola, Dziennik duchowy [21 lutego 1544 r.], w tenże, Pisma wybrane..., s. 333. 
Święta Teresa z Avila, pisząc o swoim „małżeństwie duchowym”, przez które dzięki przychylności Bożej została wprowadzona do „mieszkania” Bożego, stwierdza:

Poprzez widzenie intelektualne, poprzez pewien rodzaj uobecnienia prawdy, ukazuje jej się Najświętsza Trójca, wszystkie Trzy Osoby - dzięki pewnemu rozpłomienieniu, które najpierw przychodzi do jej ducha na sposób obłoku o przeogromnej jasności oraz te Osoby oddzielnie, poprzez zadziwiającą znajomość [Ich], która zostaje dana duszy, i rozumie z największą [pewnością] prawdy, że wszystkie Trzy Osoby są jedną substancją i jedną mocą, i jedną wiedzą, i jednym jedynym Bogiem ${ }^{44}$.

Ta wizja intelektualna św. Teresy jest jednym z najbardziej wymownych świadectw, że doświadczenie mistyki chrześcijańskiej ma swój przedmiot formalny w wizji Trójcy Świętej, streszczonej w symbolu wiary Kościoła.

\section{SYMBOL WIARY I EKSTAZA}

Jaka relacja zachodzi między wiarą chrześcijańską i doświadczeniem mistycznym? Między poznaniem Boga „oczami wiary” i jego poznaniem doświadczonym osobowo i zmysłowo przez mistyków? Czy zachodzi przeciwstawienie między wiarą i kontemplacją mistyczną? Protestancka teologia dialektyczna - np. Emil Bruner - dokonała radykalnego przeciwstawienia między słowem Bożym przyjętym w czystej wierze a mistyką opartą na doświadczeniu religijnym ${ }^{45}$. W ogólnej perspektywie protestanckiej mistyka jest zjawiskiem właściwym dla religii niechrześcijańskich, będąc prostym owocem technik oczyszczenia wewnętrznego i podniesienia duszy, osiąganych dzięki osobistemu wysiłkowi ze szkodą dla darmowości łaski i usprawiedliwienia; dziedzina wiary chrześcijańskiej byłaby natomiast zdominowana jedynie przez ,,proroctwo", to znaczy przez przekazywanie słowa Bożego przyjętego w wierze. Karl Barth pytał krytycznie w tym samym duchu: „Głębokość, którą osiąga mistyka, może być tajemnicą świata lub jego duszy, ale co ma ona wspólnego z głębokością Boga?"46.

$\mathrm{Z}$ takiego ujęcia wynika radykalna alternatywa protestantyzmu: albo Ewangelia, albo kontemplacja - albo wiara, albo mistyka. Odnośnie do mistyki chrześci-

44 Teresa od Jezusa, Zamek wewnętrzny, czyli Mieszkania [7, 6], thum. D. Wandzioch, W. Ciak, Poznań 2009, s. 264 (Dzieła Wszystkie, 2).

45 Por. E. Brunner, Die Mystik und das Wort, Tübingen 1924.

46 K. Barth, Kirchliche Dogmatik, t. 1/2, Zürich 1945, s. 839. 
jańskiej protestantyzm pozostaje więc głęboko nieufny. To pozbawienie teologii wszelkiego elementu kontemplacyjnego w protestantyzmie von Balthasar określił jako „odestetyzowanie teologii”, wyjaśniając:

W odniesieniu do naszego problemu oznacza to alternatywę między radykalną deestetyzacją i paradoksalną estetyzacją teologii, która wewnętrznie woła o nowe, oczyszczające obrazoburstwo. Deestetyzacja dokonuje się w postaci dawnej ortodoksji, która ciągle atakuje wszystkie wyrażone i przyjęte formy religii - poczynając od justitia mere imputativa (Melanchton), aż po odrzucenie wszelkich ludzkich „naczyń” i ,postaci” łaski w liturgii i zwyczajach na korzyść samej „wewnętrzności” wiary ${ }^{47}$.

W świetle teologii protestanckiej cały świat zewnętrzny postrzegany zmysłowo, a więc także dzieje ludzkie i „to, co czynione” przez człowieka, zostaje pozbawione znaczenia na korzyść czystej wewnętrzności subiektywnej.

Przeciw redukcjom teologii protestanckiej i przeciw pojawiającemu się niekiedy jednostronnemu akcentowaniu „mistycyzmu” w chrześcijaństwie ${ }^{48}$, należy jednoznacznie podkreślić, że nie istnieje żadne przeciwstawienie między wiarą chrześcijańską i jej autentycznym doświadczeniem mistycznym. Co więcej,

[...] chrześcijańskie doświadczenie mistyczne jest formą, sposobem wyrażenia wiary, możliwym, ale niekoniecznym. Chrześcijanina nie definiuje się więc, opierając się na doświadczeniu mistycznym. Doświadczenie chrześcijańskie nie jest uczuciem religijnym ani też techniką przekraczania siebie lub pełnego posiadania siebie, nawet jeśli te aspekty mogą być interesujące. Tym, co określa doświadczenie chrześcijańskie, jest jego spójność z wiarą. Jeśli więc chodzi o chrześcijańskie doświadczenie mistyczne, nigdy nie będzie ono przekroczeniem wiary: ani wiary obiektywnej [...], ani wiary subiektywnej - rozumianej jako łaska wiary. Mistyk nie posiada wizji uszczęśliwiającej, ale doświadcza szczególnego sposobu przeżywania rzeczywistości wiary. W obecnym doświadczeniu mistyk nigdy nie wykracza poza wiarę, nadzieję i miłość, w związku z czym tym, co określa chrześcijanina, nigdy nie będzie mogło być doświadczenie mistyczne, ale będzie to zawsze wiara, nadzieja i miłość. Nie ma więc chrześcijańskiego doświadczenia mistycznego poza doświadczeniem w ramach wiary ${ }^{49}$.

Święty Jan od Krzyża, mistyk „nocy ciemnej”, tak mówi o wierze w relacji do mistycznego rozumienia Trójcy Świętej:

47 H.U. von Balthasar, Chwała..., s. 41.

48 Por. Th. Merton, Drogowskazy. Fałszywa mistyka, mistycyzm, pokój monastyczny, Wrocław 1998.

49 G. Moioli, L'esperienza spirituale. Lezioni introduttive, Milano 1994, s. 73. 
[Wiara] jest jedynym, proporcjonalnie najodpowiedniejszym, środkiem zjednoczenia duszy z Bogiem. Takie bowiem jest podobieństwo między wiarą a Bogiem, jak między Bogiem widzianym (w widzeniu uszczęśliwiającym, które będzie w niebie) a poznawanym przez wiarę. Bóg jest nieskończony i wiara takim Go nam przedstawia. Bóg jest jeden w trzech Osobach i wiara podaje Go nam Troistego w jedności. Bóg jest ciemnością dla naszego rozumu i wiara również oślepia i pozbawia światła nasz rozum. Tak więc, przez ten sam środek, objawia się Bóg duszy w boskim świetle, przewyższającym wszelkie zrozumienie. Dlatego im większą wiarę ma dusza, tym więcej jest z Bogiem zjednoczona ${ }^{50}$.

Henri de Lubac, odwołując się do doświadczenia kontemplacyjnego św. Jana od Krzyża, stwierdza: „Mistyka jest wewnętrznością wiary przez uwewnętrznienie tajemnicy” i ,im bardziej postępuje się w doświadczeniu wewnętrznym, tym głębiej wnika się w wiarę"; ponadto zasadnicze znaczenie ma podkreślenie, że „doświadczenie mistyczne chrześcijanina nie jest pogłębieniem siebie: ono jest w sercu jego bytu pogłębieniem wiary" 51 , to znaczy niewymownej tajemnicy Boga Trójcy objawionej widzialnie przez Jezusa Chrystusa (por. J 1,18; 6,46; $1 \mathrm{~J} 4,12$ ). To objawienie zostało niejako skondensowane w credo Kościoła i dane do dyspozycji wierzącym.

Droga mistyki chrześcijańskiej pozostaje więc zawsze drogą „czystej wiary”, jak nazywa ją Fénélon ${ }^{52}$; jest ona pełną dyspozycyjnością w stosunku do słowa Boga i do pełnienia Jego woli, całkowitą przejrzystością - w coraz czystszej i coraz bardziej bezinteresownej miłości - nastawiona na nadprzyrodzony dar łaski Bożej i na działanie Ducha Świętego. Droga oglądu wiary, podtrzymywanej i ożywianej przez miłość nadprzyrodzoną, jest tą, którą wnikliwie ukazał św. Augustyn, gdy stwierdził, że dostęp do kontemplacji Boga Trójcy otwiera się przed człowiekiem w znaku miłości: „Tak, widzisz Trójcę, jeśli widzisz miłość. [...] Miłość zakłada kogoś, kto kocha, a miłością kocha się coś. Oto trzy rzeczywistości: Miłujący, Miłowany i Miłość" 53 . W trynitarnej tajemnicy Boga są nimi Ojciec, Syn i Duch Święty, wspólna Miłość Ojca i Syna.

Mistyka chrześcijańska rozumiana jako doświadczenie Boga nie tylko nie wychodzi poza porządek wiary, ale sytuuje się ,,wewnątrz logiki życia wiary. Nie żywi się niczym innym: przyjmuje ona tajemnicę, nie dlatego że jest wyznawa-

50 Jan od Krzyża, Droga na Górę Karmel [2, 9, 1], w: tenże, Dzieła, thum. B. Smyrak, Kraków $2014^{8}$, s. 265.

51 H. de Lubac, Mistica e mistero cristiano..., s. 22-24.

52 Por. Fénélon, Oeuvres spirituelles, t. 4, Nancy 1835, s. 132-135.

53 Augustyn, De Trinitate 8, 8, 12 i 9, 14, PL 42, 958-960. 
na ustami, ale w sensie właściwym - ponieważ jest przeżywana" ${ }^{54}$. Doświadczenie mistyczne, nawet najwznioślejsze, przeżywane jako „zaślubiny duchowe” z Bogiem, jest właściwe dla chrześcijanina, który postępuje ,według wiary, a nie dzięki widzeniu" (2 Kor 5,7), to znaczy gdy naśladuje Jezusa Chrystusa i w wierności zmierza do stania się doskonałym, jak doskonały jest Ojciec niebieski (por. Mt 5,48). Święty Jan od Krzyża podkreśla:

Postęp bowiem to nic innego jak tylko naśladowanie Chrystusa, który ,,jest drogą, prawdą i życiem i nikt nie przychodzi do Ojca inaczej jak tylko przez Niego", jak to sam mówi przez św. Jana $(14,6)$. [...] Nie jest więc oznaką dobrego ducha, jeśli ktoś chce iść przez słodkości i wygody, uciekając od naśladowania Chrystusa ${ }^{55}$.

„Nie ma więc bardziej wyjątkowego daru Bożego niż miłość” - stwierdza św. Augustyn w De Trinitate, tak rozwijając tę ideę: „Miłością, która jest darem Bożym i którą jest Bóg, jest właściwie Duch Święty, przez którego zostaje wylana w naszych sercach miłość Boża, sprawiając, że cała Trójca mieszka (inhabitet) w nas” jak w świątyni ${ }^{56}$. Podobnie wyjaśnia św. Tomasz z Akwinu: „Miłość jest pierwszym darem, na mocy którego są nam dawane wszystkie darmowe dary. Ponieważ jest ustalone, że Duch Święty pochodzi jako miłość, pochodzi także jako pierwszy dar"'57.

Cała teologia biblijna daje szerokie potwierdzenie nieodłącznej obecności wiary w mistycznym doświadczeniu Boga. Wystarczy pomyśleć o mistycznej kontemplacji Boga przeżywanej przez św. Pawła, o czym wielokrotnie sam zaświadcza w swoich pismach, nadając szerokie znaczenie prymatowi czystej wiary, aby wejść do królestwa Bożego i aby zostać usprawiedliwionym. Apostoł stale podkreśla swoje niezmierzone pragnienie zjednoczenia z Chrystusem w życiu i w śmierci, w radości i w bólu, w działalności apostolskiej i w ludzkich porażkach. Najgłębszym dążeniem Apostoła Narodów było stracić wszystko ,ze względu na najwyższą wartość poznania Chrystusa Jezusa, mojego Pana”, dlatego - kontynuuje - ,dla Niego wyzułem się ze wszystkiego i uznaję to za śmieci, bylebym pozyskał Chrystusa i znalazł się w Nim - nie mając mojej sprawiedliwości, pochodzącej z Prawa, lecz Bożą sprawiedliwość, otrzymaną dzięki wierze w Chrystusa" (Flp 3,8-9). Nawiązując do swego pierwszego doświadczenia mistycznego pod Damaszkiem, apostoł podsumowuje swoje wyznanie, tak określając cel swoich

54 H. de Lubac, Mistica e mistero cristiano..., s. 20.

55 Jan od Krzyża, Droga na Górę Karmel [2, 7, 8], w: tenże, Dzieła, s. 258; por. J.S. Pelczar, O mistyce, Kraków 2014, s. 26-27.

56 Augustyn, De Trinitate 15, 18, 32, PL 42, 1083.

57 Tomasz z Akwinu, Summa theologiae, I q. 36 a. 2. 
dążeń wypływających z dogłębnie przeżywanej wiary: „Abym też [to] zdobył, bo i sam zostałem zdobyty przez Chrystusa Jezusa" (Flp 3,12).

Święty Paweł łączy w sposób nierozdzielny wiarę i poznanie Chrystusa, którego doświadczył także widzialnie i zmysłowo w czasie Jego zjawień się jako Zmartwychwstałego. Nie waha się on mówić o swoich nadzwyczajnych wizjach mistycznych, o tym, że „został porwany aż do trzeciego nieba” (2 Kor 12,2). W doświadczeniu mistycznym, jako wewnętrznej komunii z Bogiem, św. Paweł przyznaje prymat nie dążeniu i wysiłkowi człowieka, by dojść do Boga, ale przede wszystkim całkowicie wolnej inicjatywie Boga, który pozwala się poznać człowiekowi, objawiając w Jezusie Chrystusie swoją „ukrytą” tajemnicę (1 Kor 2,7; Ef 3,9; Rz 16,25-27). Wszystko to zakłada szczególny i oryginalny obraz Boga, który warunkuje nowe pojęcie „mistyki” ${ }^{58}$. Bóg Pawła i chrześcijan nie jest już odległym i niedostępnym bóstwem klasycznej filozofii greckiej, nie jest bezosobową i panteistyczną zasadą uniwersalną stoików ani też mitycznym i naturalistycznym bóstwem kultów misteryjnych, czy wreszcie jakimś dobrym bogiem dualistycznie przeciwnym złej istocie bożej, usiłującej wszystko sobie podporządkować jak w gnostycyzmie. Apostoł nie zachowuje w swojej teologii także rygorystycznej transcendencji Boga żydowskiego, który co najwyżej usiłuje uczynić z ludzkiego zachowywania Prawa miarę wspólnoty z sobą. Dla Pawła Bóg jest przede wszystkim „Ojcem Pana Jezusa Chrystusa” (2 Kor 1,3; 11,31; Rz 15,6; Kol 1,3; Ef 1,3), dzięki czemu także ochrzczony może zwracać się do Niego zażyłym wezwaniem „Ojcze”, tym bardziej że otrzymał w swoim sercu „Ducha Jego Syna" (por. Ga 4,6; Rz 8,15). Wszystko to oznacza, że Bóg wyszedł już na spotkanie człowiekowi, przechodząc przez krzyż i zmartwychwstanie Chrystusa oraz stale pozostaje otwarty na zintensyfikowanie ludzkiej relacji w stosunku do Niego. W każdym jednak razie pozostaje nienaruszone pryncypium, że pierwszy kontakt człowieka z Bogiem łaski dokonuje się przez wiarę w Niego i w Jego interwencję zbawczą dokonaną w Jezusie Chrystusie. Dla św. Pawła kluczową sprawą w każdej sytuacji pozostaje obrona prymatu wiary, a zwłaszcza jego pozytywne utrwalenie, którego potwierdzeniem jest jej przeżywanie w miłości (por. Ga 5,8).

\section{ZAKOŃCZENIE}

Jak wszystkie charyzmaty duchowe, także mistyczny dar kontemplacji wlanej nie tylko jest dawany ze względu na uświęcenie osobiste, ale posiada także

58 Por. A. Schweitzer, Die Mystik des Apostels Paulus, Tübingen 1930; Ch.A. Bernard, San Paolo mistico e apostolo, Milano 2000; F. Pieri, L'itinerario di cristificazione di Paolo di Tarso. Caratteristiche di una esperienza di Dio, Roma 2011. 
funkcję eklezjalną i społeczną, a nawet kulturową, to znaczy służy uświęceniu innych. Oddziaływanie zbawcze słowa Bożego, dyspozycyjność w stosunku do Boga, rezygnacja z siebie, aby zrobić Mu miejsce, są także wyrazem gotowości do podejmowania na nowo służby Bożej i poświęcenia się dla braci. Miłość do Boga i do braci jest cnotą, która oświeca każde głębokie doświadczenie mistyczne i w niej to doświadczenie się wyraża odpowiednio do okoliczności duchowych i eklezjalnych, w których znajduje się mistyk. Jest to mistyka służby na rzecz Boga i Chrystusa, a także Kościoła. Taką mistykę można spotkać u wielu świętych w Kościele. W sposób szczególny można zauważyć, że najwznioślejsza mistyka, z punktu widzenia przedmiotowego, zawsze ma odniesienie do Trójcy Przenajświętszej. Niemniej jednak to najwyższe odniesienie do Boga staje się także charyzmatyczną służbą na rzecz bliźnich, kształtując ogólne ukierunkowanie życia chrześcijańskiego w Kościele.

Wobec charyzmatycznego działania Bożego, które wyraża się w doświadczeniu mistycznym, dusza duchowa czuje zwłaszcza wezwanie do podęcia służby na rzecz Boga i włączenia w nią wszystkich swoich władz duchowych: intelektualnych, wolitywnych i zmysłowych. W takim przypadku doświadczenie mistyczne wyzwala rzeczywiście w świetle prymatu Boga wszystkie swoje możliwości apostolskie w służbie królestwa Boga i Jego chwały. Na tym poziomie doświadczenie mistyczne, charakteryzujące się zakorzenioną w wierze i miłości kontemplacją Trójcy Przenajświętszej, zachowuje swój charakter świadectwa wiary danego przez Boga Kościołowi w wędrówce oczyszczenia, aby mógł w końcu dojść do swego celu - niebieskiego Jeruzalem, gdy „Bóg będzie wszystkim we wszystkich" (1 Kor 15,28).

\section{BIBLIOGRAFIA}

Ancilli E., La mistica alla ricerca di una definizione, w: La mistica. Fenomenologia e riflessione teologica, red. E. Ancilli, M. Paparozzi, t. 1, Roma 1984, s. 17-40.

Atanazy, Listy do Serapiona, tłum. S. Kalinkowski, Kraków 1996 (Źródła Myśli Teologicznej, 2).

Augustyn, De Trinitate, PL 42.

Augustyn, Piotr Chryzolog, Wenancjusz Fortunatus, Symbol Apostolski w nauczaniu ojców, tłum. L. Gładyszewski, Kraków 2010 (Źródła Myśli Teologicznej, 53).

Balthasar H.U. von, Duch chrześcijański, tłum. Z. Włodkowa, Paris 1976.

Balthasar H.U. von, Lo Spirito e l'istituzione. Saggi teologici-IV, Brescia 1979.

Balthasar H.U. von, Thomas und die Charismatik. Kommentar zu Thomas von Aquin „Summa Theologica”, Quaestiones II II 171-182. Besondere Gnadengaben und die zwei Wege menschlichen Lebens, Freiburg i. Br. 1996. 
Balthasar H.U. von, Chwata. Estetyka teologiczna, t. 1: Kontemplacja postaci, thum. E. Marszał, J. Zakrzewski, Kraków 2008.

Balthasar H.U. von, Chwała. Estetyka teologiczna, t. 2: Modele teologiczne, cz. 1: Od Ireneusza do Bonawentury, thum. E. Marszał, J. Zakrzewski, Kraków 2007.

Barth K., Kirchliche Dogmatik, t. 1/2, Zürich 1945.

Bernard Ch.A., L'esperienza spirituale della Trinità, w: La mistica. Fenomenologia e riflessione teologica, red. E. Ancilli, M. Paparozzi, t. 2, Roma 1984, s. 295-321.

Bernard Ch.A., San Paolo mistico e apostolo, Milano 2000.

Bouyer L., Mysterion. Dal mistero alla mistica, Città del Vaticano 1998.

Brunner E., Die Mystik und das Wort, Tübingen 1924.

Castellano Cervera J., Il mistero di Dio Uno e Trino nella testimonianza dei mistici cristiani, w: Il Dio di Gesù Cristo, red. G.M. Zangí, Roma 1982, s. 253-274.

Claudel P., Le Cantique des cantiques, Paris 1954.

Eliade M., Historia wierzeń i idei religijnych, t. 1: Od epoki kamiennej do misteriów eleuzyńskich, tłum. S. Tokarski, Warszawa 1988.

Falque E., Le livre de l'expérience. D'Anselme de Cantorbéry à Bernard de Clairvaux, Paris 2017.

Fénélon, Oeuvres spirituelles, t. 4, Nancy 1835.

Finkenrath G., Mistero, w: Dizionario dei concetti biblici del Nuovo Testamento, red.

L. Coenen, E. Beyreuther, H. Bietenhard, Bologna $1989^{4}$.

Gerson J., O teologii mistycznej, thum. M. Jakubowska, Kęty 2012.

Guibert J. de, La spiritualità della Compagnia di Gesù. Saggio storico, Roma 1992.

Hahn A., Hahn G.L., Bibliothek der Symbole und Glaubensregeln der alten Kirche, Breslau $1897^{3}$.

Ignacy Loyola, Pisma wybrane, t. 1: Komentarze, oprac. M. Bednarz, przy współpracy S. Filipowicza, R. Skórki, Kraków 1968.

Jalabert L., Monterede R., Inscriptions greques et latines de la Syrie, Paris 1929.

Jan od Krzyża, Dzieła, tłum. B. Smyrak, Kraków 2014.

Jan Paweł II, Encyklika ,Redemptoris Mater”.

Jungmann J.A., Catechetica, Roma 1956.

Kilmartin E.J., Christian Liturgy: Theology and Practice. I. Systematic Theology of Liturgy, Kansas City 1988.

Królikowski J., Tajemnica Trójjedynego. Studia z teologii trynitarnej, Kraków 2015 (Ministerium Expositionis, 2).

Lubac H. de, La Foi chrétienne. Essai sur la structure du Symbole des Apôtres, Paris 1969.

Lubac H. de, Mistica e mistero cristiano, Milano 1979.

Marchesi G., Sul volto di Cristo rifulge la Gloria del Padre (2 Kor 4,6), „La Civiltà Cattolica" 2001, t. 4, s. 240-253. 
Merton Th., Drogowskazy. Fałszywa mistyka, mistycyzm, pokój monastyczny, Wrocław 1998.

Moioli G., L'esperienza spirituale. Lezioni introduttive, Milano 1994.

Pelczar J.S., O mistyce, Kraków 2014.

Peri V., Da Oriente e da Occidente. Le Chiese cristiane dall'impero romano all'Europa moderna, red. M. Ferrari, t. 2, Roma-Padova 2002 (Medioevo e Umanesimo, 108).

Pieri F., L'itinerario di cristificazione di Paolo di Tarso. Caratteristiche di una esperienza di Dio, Roma 2011.

Pseudo-Augustyn, Sermo 241, PL 39, 2190-2191.

Rahner K., Schriften zur Theologie, t. 7, Einsiedeln 1966.

Ruh K., Storia della mistica occidentale, t. 1: Le basi patristiche e la teologia monastica del XII secolo, Milano 1995.

Scheele P.-W., Schwester Maria Julitta Ritz. Maria und Marta zugleich, Würzburg 2017.

Schweitzer A., Die Mystik des Apostels Paulus, Tübingen 1930.

Starowieyski M., Legenda o powstaniu Składu Apostolskiego, w: Symbol Apostolski w nauczaniu i sztuce Kościoła, red. R. Knapiński, Lublin 1997, s. 51-62.

Teresa od Jezusa, Zamek wewnętrzny, czyli Mieszkania, tłum. D. Wandzioch, W. Ciak, Poznań 2009 (Dzieła Wszystkie, 2).

Tomasz z Akwinu, Summa theologiae.

Wybrane księgi symboliczne Kościoła ewangelicko-augsburskiego, tłum. A. Wantuła, W. Niemczyk, Warszawa 1980.

\section{TRÓJCA ŚWIĘTA I DOŚWIADCZENIE MISTYCZNE}

\section{Streszczenie}

Tajemnica Trójcy Świętej stanowi transcendentną i pierwotną zasadę dziejów zbawienia oraz pierwszy przedmiot wiary chrześcijańskiej. W relacji do tej tajemnicy kształtuje się wiara i życie chrześcijańskie. Można więc mówić o prymacie Trójcy Świętej w wierze, na co wskazuje kształtowanie się doktryny chrześcijańskiej oraz nadawany jej stopniowo kształt. Warto więc zwrócić uwagę na to, że Trójca Święta jest także przedmiotem doświadczenia mistycznego. Począwszy od Nowego Testamentu, zwłaszcza od św. Pawła, stopniowo dojrzewa w Kościele przekonanie, że najwznioślejsza relacja z Bogiem, którą jest relacja mistyczna, musi mieć charakter trynitarny. Wskazują na to wypracowane w teologii kryteria mistyki chrześcijańskiej. Szczególnym wyrazem doświadczenia mistycznego jest „ekstaza". Zakorzenia się ona w symbolu wiary, który syntetycznie ukazuje przedmiot wiary, czyli Trójcę Świętą wraz ze specyfiką jej działania zbawczego. Zniżenie się Boga do człowieka stanowi podstawę opartego na wierze wznoszenia się człowieka do Boga. We właściwym znaczeniu to zagadnienie znajduje uzasadnienie w doświadczeniu i w teologii Pawła Apostoła. 
Słowa kluczowe: Trójca, symbol wiary, wiara, mistyka, ekstaza, doświadczenie THE HOLY TRINITY AND THE MYSTICAL EXPERIENCE

\section{Summary}

The mystery of the Holy Trinity constitutes a transcendental and original principle of the history of salvation and the first subject of Christian faith. Christian faith and Christian life are both shaped in relation to this mystery. Therefore we can speak about the primacy of the Holy Trinity in the faith, which finds its expression in the gradual development and in the overall shape of Christian doctrine. It is worth noticing, that the Holy Trinity is also a subject of mystical experience. Starting with the New Testament, especially St. Paul, we can observe in the Church a progressive development of the conviction that the most elevated relation with God, that is mystical relation, has to be Trinitarian in character. It has been shown by the criteria of the Christian mysticism elaborated in theology. A special manifestation of the mystical experience is "ecstasy". It is rooted in the symbol of faith which synthetically reveals the subject of faith, that is the Holy Trinity together with the specific character of Its redemptive action. God's lowering towards man constitutes the foundation of the based on faith, man's rising towards God. In the proper meaning this issue finds its justification in the experience and theology of Paul the Apostle.

Keywords: Trinity, symbol of faith, faith, mysticism, ecstasy, experience 